\title{
Research potential and limitations of trace analyses of cremated remains
}

\author{
Michaela Harbeck ${ }^{\mathrm{a}, *}$, Ramona Schleuder ${ }^{\mathrm{a}}$, Julius Schneider ${ }^{\mathrm{b}}$, Ingrid Wiechmann ${ }^{\mathrm{a}}$, \\ Wolfgang W. Schmahl ${ }^{\mathrm{b}}$, Gisela Grupe ${ }^{\mathrm{a}}$ \\ ${ }^{a}$ Department of Biology, Anthropology, Ludwig-Maximilian-University Munich, Großhaderner Straße 2, 82152 Planegg-Martinsried, Germany \\ ${ }^{\mathrm{b}}$ Department of Geo- und Environmental Science, Ludwig-Maximilian-University Munich, Theresienstrasse 41, 80333 Munich, Germany
}

\section{A R T I C L E I N F O}

\section{Article history:}

Received 5 January 2009

Received in revised form 25 May 2010

Accepted 7 June 2010

Available online 6 July 2010

\section{Keywords:}

Cremated bone

Stable isotopes

DNA

Hydroxyl apatite

\begin{abstract}
A B S T R A C T
Human cremation is a common funeral practice all over the world and will presumably become an even more popular choice for interment in the future. Mainly for purposes of identification, there is presently a growing need to perform trace analyses such as DNA or stable isotope analyses on human remains after cremation in order to clarify pending questions in civil or criminal court cases. The aim of this study was to experimentally test the potential and limitations of DNA and stable isotope analyses when conducted on cremated remains.

For this purpose, tibiae from modern cattle were experimentally cremated by incinerating the bones in increments of $100^{\circ} \mathrm{C}$ until a maximum of $1000^{\circ} \mathrm{C}$ was reached. In addition, cremated human remains were collected from a modern crematory. The samples were investigated to determine level of DNA preservation and stable isotope values ( $\mathrm{C}$ and $\mathrm{N}$ in collagen, $\mathrm{C}$ and $\mathrm{O}$ in the structural carbonate, and $\mathrm{Sr}$ in apatite). Furthermore, we assessed the integrity of microstructural organization, appearance under UVlight, collagen content, as well as the mineral and crystalline organization. This was conducted in order to provide a general background with which to explain observed changes in the trace analyses data sets. The goal is to develop an efficacious screening method for determining at which degree of burning bone still retains its original biological signals. We found that stable isotope analysis of the tested light elements in bone is only possible up to a heat exposure of $300{ }^{\circ} \mathrm{C}$ while the isotopic signal from strontium remains unaltered even in bones exposed to very high temperatures. DNA-analyses seem theoretically possible up to a heat exposure of $600^{\circ} \mathrm{C}$ but can not be advised in every case because of the increased risk of contamination. While the macroscopic colour and UV-fluorescence of cremated bone give hints to temperature exposure of the bone's outer surface, its histological appearance can be used as a reliable indicator for the assessment of the overall degree of burning.
\end{abstract}

(c) 2010 Elsevier Ireland Ltd. All rights reserved.

\section{Introduction}

The cremation of humans has become a progressively more common practice in modern times. Presently, nearly $100 \%$ of all inhumations in Japan are cremations and in Europe the figure has risen to about 30\% [1]. According to the Cremation Association of North America [2], approximately 33.5\% of those who died in North America in 2006 were cremated. They also predict that by 2025 more than $45 \%$ of all inhumations in the United States will take place in a crematory. Forensic finds frequently consist of human bodies or body parts which had been exposed to high temperatures through fire, for example, in mass disasters or following intentional immolation in order to conceal a homicide (e.g. [3,4]). However, cremated remains are also common in the archaeological context. For a period spanning roughly 1500 years, from the upper Bronze

\footnotetext{
* Corresponding author. Tel.: +49 892180 74319; fax: +49 89218074331.

E-mail address: M.Harbeck@lrz.uni-muenchen.de (M. Harbeck).
}

Age until the early Middle Age, cremation was the predominant burial custom in Europe. Therefore, the retrieval of detailed information pertaining to the individual or population such as those collected from non-cremated bones utilizing the current methodological spectrum is highly desirable, not only for forensic scientists, but also anthropologists focusing on historical human remains in particular.

A recently published review by Ubelaker [5] shows that numerous studies have been performed with regard to the macroand micromorphological temperature-induced changes in bone (e.g. [6-10]) and the structural changes in the mineral portion related to the degree of heat exposure (e.g. [11-16]). The modifications incurred upon intact bone when exposed to higher temperatures are as follows, although it should be noted that temperature ranges may vary according to the cremation conditions [5]: between 150 and $300{ }^{\circ} \mathrm{C}$ a loss of chemically bound water and the degradation of the organic matrix is observable. Bone changes its original colour at temperatures ranging between 300 and $600{ }^{\circ} \mathrm{C}$ in the order of brown $\rightarrow$ black $\rightarrow$ grey resulting from the oxidation of organic 
carbon, the combustion of which is completed around $800{ }^{\circ} \mathrm{C}$. A solid state chemical reaction sets in at approximately the same temperature leading to the formation of tricalciumphosphate. At this point the bone turns white and its microstructural appearance is homogenous while exhibiting an absence of birefringence.

Few studies focus on the possibility of amplifying authentic DNA (e.g. [17-20]; for a review see [5]) or the analysis of organic tissue components from cremated remains $[14,21,13]$. There is a pressing need for molecular genetic investigations on cremated remains, to provide assistance to forensic scientists in the clarification of criminal and civil cases, for example in the identification process of missing or deceased persons or in establishing kinship to resolve problems involving paternity, but also to help anthropologists find answers to pending historical questions. Yet no consensus has been reached regarding the degree of cremation (charred to completely cremated) at which bone will still yield authentic DNA signals. In the event that morphological skeletal identification or DNA analyses both produce negative results, stable isotope analyses can provide clues to the life history of an individual or its geographical origin that in turn may lead to a positive identification [22-26]. Stable isotope analyses have proven a powerful tool in anthropology and play a major role in the reconstruction of life histories of ancient populations (for a review see [27]).

The potential and possibilities offered by stable isotope analyses on cremated bones appear in only a few studies, and these focus on stable isotope analyses of light elements or radiocarbon dating [21,28-31].

The goal of the study presented here is to determine the maximum degree of bone cremation that can be reached at which robust, original signals from DNA and stable isotope analyses (light and heavy elements) can still be retrieved. To accomplish this, bones were experimentally cremated (with the exception of a control sample) at different temperatures and subsequently tested to confirm whether DNA-amplification was possible and if original stable isotope values could be retrieved. A sample set of burned bones collected from a modern crematory was also tested for this purpose.

Rather than simply presenting the empirically generated results, the intention here is to elucidate the reasons behind the observed altered signals of stable isotopes and DNA in cremated bones and their relationship to the aforementioned high temperature modification process of bone.

Requisite steps included determining the state of preservation of bone collagen (collagen-weight-percentages and quality indicators) and mineral (X-ray diffraction), examining the thermal behavior and weight loss of a sample (Thermogravimetric (TGA), and performing differential thermal analyses (DTA)) during the cremation process.

A further goal of this study was to employ and test simple methods such as colour definition, histology and, for the first time, UV-fluorescence for their ability to determine the temperature a specific sample had been exposed to and to assess the resulting potential success regarding the application of DNA and stable isotope analyses.

\section{Materials and methods}

Three tibiae of modern cattle provided by the Department of Veterinary Medicine at the Ludwig-Maximilian-University in Munich were cut into 11 cross sections. These had a thickness of $1 \mathrm{~cm}$ and were further divided into quarters. The fat content in fresh bone (such as those used for the control and low temperature treatments) must first be removed because remnants of fatty acids can skew carbon isotopic data [27,32] and interfere with histological analyses. All samples were therefore defatted with diethyl-ether in a soxhlet extraction device to create equal conditions.

One cross section was left uncremated and served as a control. The rest were heated in a muffle furnace under oxidizing conditions in increments of $100{ }^{\circ} \mathrm{C}$ beginning at $100^{\circ} \mathrm{C}$ (i.e. $200,300^{\circ} \mathrm{C}, \ldots$ ) until $1000^{\circ} \mathrm{C}$, which is a temperature reached by recent crematories and even by prehistoric funeral pyres [33]. Tibiae sections I and II were heated for one and a half hours each, whereas tibia sections for sample III were cremated for $4 \mathrm{~h}$.

The corresponding cremated quarters of each cross section were used for every analysis performed (see below). However, due to the limited amount of material, not all trace analyses could be performed on all three tibiae. Unheated samples of Tibia III were used to perform thermogravimetric and differential thermal analysis (see below).

In addition, the bones of ten individuals cremated in a modern crematory (K91K100), with known DNA-preservation [34], were examined to assess their histological appearance, UV-fluorescence and stable isotope values of light elements. Because of the unambiguous results gathered from the analyses of heavy isotopes from the experimentally cremated bones it was not necessary to analyze these on the crematory material. Although ethical considerations prevented the removal of a corresponding control bone from each of the bodies prior to burning, a femur sample of one single adult male that had undergone an autopsy and originated from the same time and region was taken as a control. The authenticity of the retrieved DNAfingerprints was ensured in a previous study [34] by comparison of the results with fingerprints from buccal swabs, which were taken from the bodies before cremation.

Investigations of histological appearance and UV-fluorescence were conducted after burning but before the cremated bone fragments were ground (burned bone fragments are routinely ground in modern crematoria). All other analyses took place on ground material.

\subsection{Assessments of colour, UV-fluorescence and histological appearance}

The colour of the samples, their UV-fluorescence and histological appearance (only from Tibia II and the bone fragments from the modern crematory) were evaluated.

Fluorescence was investigated from samples deriving from Tibiae II and III and the cremated remains from the modern crematory. The samples were exposed to a UV light wave length of $366 \mathrm{~nm}$ with the light source positioned above the bone sections. In order to define the fluorescence colour, the sample was inspected simultaneously with both a positive and a negative control. The positive control was fresh bone that characteristically displays an intense light-blue fluorescence. Severely degraded archaeological bone lacking this light-blue fluorescence served as the negative control [30]. Digital images of the fluorescence light were processed using ADOBE Photoshop 6.0.2 software. Tonal value was optimized by the software automatically.

Samples intended for histological examination were embedded in Biodur E12 resin (BIODUR ${ }^{\mathrm{TM}}$ PRODUCTS), cut into sections of $80 \mu \mathrm{m}$ thickness with a microtome (Leica SP 1600). and inspected using a light microscope (ZEISS, Axioskop 2 plus; equipped with a digital camera ZEISS, AxioCam MRc colour) at $50 \times$ magnification under both bright and polarized light.

\subsection{Mineral analyses: $X$-ray diffraction}

$\mathrm{X}$-ray powder diffraction is an analytical method that reflects the crystal structure on an atomic scale by the positions and intensities of the diffraction lines. It is also a tool to measure crystallite size (e.g. unit cell volume) and microstrain on a nanometric scale by the diffraction line widths. Based on this concept, sample crystallinity was assessed by the "half width crystallinity index" ( $\mathrm{HW}-\mathrm{Cl}$ ) defined as the ratio between the intrinsic line width of the diffractometer (as measured by a suitable standard powder) and the line width of the sample powder. Additionally, the "peak height crystallinity index" PH-CI after Person et al. was also calculated [35].

This was accomplished by grinding the samples of Tibia III in an agate mortar and swing mill (RETSCH MM 200). They were then mixed with approximately 30 vol.\% silicon powder, which served as a standard for internal line position and line profile width. The powder was mixed thoroughly, subsequently glued to a mylar foil and mounted on a STOE STADIP focussing powder diffractometer in transmission geometry. This instrument is equipped with a curved primary $\mathrm{Ge}\left(\begin{array}{lll}1 & 1 & 1\end{array}\right)$ monochromator for Mo-K-alpha 1 radiation $(\lambda=0,7093 \mathrm{~A} \bumpeq 70,93 \mathrm{pm})$ and a 6 position sensitive detector. Data were collected in steps of $0.02^{\circ}-2$-Theta with total data collection times of $24 \mathrm{~h}$ to collect 8 diffractograms from $3^{\circ}$ to $53^{\circ} 2$-Theta which were then averaged. The diffractograms were evaluated with the Rietveld profile fitting method [36]. The diffraction intensities were calculated on the basis of the crystal structure data of monoclinic hydroxyapatite [37] and the silicon standard. Diffraction lines were modelled with the pseudo-Voigt profile function of the Rietveld-code FULLPROF [38]. The background, including potential amorphous components, was fitted as a polynomial function of 2-Theta.

\subsection{Thermogravimetric (TGA) and differential thermal analyses (DTA)}

The thermogravimetric analysis (TGA) performed is designed to monitor the change in sample weight as a function of rising temperature. In addition, concurrent differential thermal analysis (DTA) was conducted to measure the difference $\Delta T$ between the sample and an inert reference material $\left(\mathrm{Al}_{2} \mathrm{O}_{3}\right.$, in our case $)$ as a function of rising or falling temperature. Both experiments were performed on a thermomicrobalance based simultaneous TGA-DSC calorimeter at a heating rate of $10^{\circ} \mathrm{C} / \mathrm{min}$ up to $1000^{\circ} \mathrm{C}$ using $40 \mathrm{mg}$ samples in a Pt-crucible and under Argon 5.0 protective gas. Due to the different thermal treatment and oxygen fugacity, results of this thermal analysis may deviate slightly from the results of X-ray diffraction, which used samples annealed in a pre-heated furnace for $4 \mathrm{~h}$ isothermally. 


\subsection{DNA analysis}

All preparatory steps for DNA analysis of the experimentally cremated bones were performed according to the necessary precautions to avoid any form of contamination. These include the spatial separation of pre- and post-PCR areas, the decontamination of chemicals, laboratory devices and work spaces by UV-radiation and/or cleaning with sodium hypochlorite, and the use of one-way disposable gloves, hair and face masks. Negative controls accompanied every extraction and PCR.

All surfaces of the sample were exposed to UV-radiation at $254 \mathrm{~nm}$ for $15 \mathrm{~min}$. The samples were then homogenized in a swing mill (RETSCH). DNA was extracted according to two different protocols (see Yang et al. [39]), and by use of the InViSorb Forensic Kit I (InViTek). Although cattle tibiae are rather large bones, the variety of methods applied here consumed a significant amount of material. As a result, both extraction protocols were applicable only to the samples from Tibia I. DNA was extracted from Tibia III by the InViSorb protocol only.

A DNA sequence of 129 bp from the mitochondrial HVS1 region (nt 16165-nt 16293, GenBank accession number V00654) was amplified (PX 0.2 Thermal-CyclerSystem, Hoefer comp., 50 cycles) according to the method published by Bollongino et al. [40]:

\section{H16184 5'-TACCATGCCGCGTGAAACCA-3'}

L16272 5'-TGAGATGGCCCTGAAGAAAGAA-3'

$5 \mu \mathrm{l}$ of the amplification products were separated on a $2 \%$ ethidiumbromideagarose gel and identified according to their length. Three PCRs were performed per extraction. In cases where all three PCR products led to a clear signal on the gel, preservation and success of amplification of DNA in the sample was assumed. Subsamples of the amplification products of samples which had been cremated at 0 $200,400,600{ }^{\circ} \mathrm{C}$ and, if retrievable, $700{ }^{\circ} \mathrm{C}$ were sequenced to assure the authenticity of the amplification products (Sequencing Service of the Faculty of Biology, Genomics Service Unit, University of Munich).

STR-Fingerprints of the modern human cremations and the corresponding buccal swabs have been published previously by von Wurmb-Schwark et al. [34].

\subsection{Collagen and stable isotope analysis}

Collagen isotopic analyses were performed on the samples of all three cattle tibiae and those from a modern crematory. Carbonate and strontium isotopic analyses were performed on Tibiae I and II only. Carbonate isotopic analyses were also carried out on the cremated remains from the modern crematory and the modern control bone.

Collagen was extracted as gelatine according to the procedure indicated by Longin [41], however, with some modification [42]. The amount of extracted gelatine in relation to the weight of the whole bone sample will be referred to as collagen weight proportion in percent (wt.\%).

The $\delta^{15} \mathrm{~N}$ and $\delta^{13} \mathrm{C}$ in the extract were analyzed by a coupled CHN-Analyzer (Thermo Finnigan NA2500)/Mass spectrometer (Thermo Finnigan Delta plus) as published previously [42]. This system also determines necessary indicators of quality including carbon (C\%) and nitrogen (N\%) weight percentages $(\mathrm{C} \%)$ and $\mathrm{C} / \mathrm{N}$ molar ratios. Isotopic ratios are expressed in relation to the PDB $\left(\delta^{13} \mathrm{C}\right)$ and AIR $\left(\delta^{15} \mathrm{~N}\right)$ standards in the conventional $\delta$-notation.

Bone structural carbonate was extracted according to Balasse et al. [43]. $\delta^{18} \mathrm{O}$ and $\delta^{13} \mathrm{C}$ in carbonate were analyzed by a coupled analyzing system Gasbench II/Delta plus (Thermo Finnigan) as published in Grupe et al. [42]. Isotopic ratios are expressed in the conventional $\delta$-notation against PDB standard.

Extraction of apatite and measurement of ${ }^{87} \mathrm{Sr} /{ }^{86} \mathrm{Sr}$ ratios with a thermal ionisation mass spectrometer Finnigan MAT 261 were performed as stated in [44].

\section{Results}

\subsection{Experimentally cremated cattle bones}

An overview of the results arranged according to their purpose is listed in Table 1.

\subsubsection{Indicators for success of DNA or stable isotope analyses}

All three experimentally cremated tibiae exhibited a change in colour at rising temperatures from brown to black to grey to white. As seen in Table 1, the temperature specific colouration differed only slightly in individual cases between the three tibiae. The colour of the UV-fluorescence exhibited by the cremated bones also changed (Table 1 ). Initial alteration of bone microstructure first became visible at $200{ }^{\circ} \mathrm{C}$, manifested as small fissures. However, marked deterioration of the original microstructure took place at $500{ }^{\circ} \mathrm{C}$ onwards and the first signs of reduced birefringence were observed at $600{ }^{\circ} \mathrm{C}$. At $800{ }^{\circ} \mathrm{C}$ and above, the original histological appearance disappeared entirely, structural elements were no longer distinguishable and birefringence ceased.
Only the sample exposed to $300{ }^{\circ} \mathrm{C}$ could not be evaluated for UV-fluorescence and microstructural preservation, both of which were prevented by the intense blackening throughout the bone.

\subsubsection{Indicators for the overall modification process}

Diffractogram examination of the powder's mineral fraction showed no major crystalline phases other than hydroxyapatite. Only at temperatures exceeding $600{ }^{\circ} \mathrm{C}$ was a minor phase of $1.6 \mathrm{wt} . \% \mathrm{MgO}$ found. Some other unidentified minor peaks (located at lattice spacings $d=2.20,2.01$ and $1.92(\sim 3-5 \%$ of the intensity of the largest hydroxyapatite peak)) were also seen.

Fig. 1 displays the dependence of the full width at half maximum (FWHM) for $37.0^{\circ}$ 2-Theta as a function of cremation temperature. The FWHM decreases only slightly at an increase in temperature of $100-200{ }^{\circ} \mathrm{C}$ with no further change up to $400{ }^{\circ} \mathrm{C}$. The most important reduction in line width occurs between 500 and $700{ }^{\circ} \mathrm{C}$, remaining constant for temperatures up to $1000^{\circ} \mathrm{C}$. This may indicate that recrystallization is complete at $700^{\circ} \mathrm{C}$. However, at $700{ }^{\circ} \mathrm{C}$ the width of the peaks reaches the line width as determined by the instrumental resolution, so that any further recrystallization might not be detectable.

The crystallinity indices, as derived from line width ratios (HW$\mathrm{CI}$ ) and from peak height/"background"-ratios (PB-CI), respectively, are shown in Fig. 2. The inverse relationship between $\mathrm{HW}-\mathrm{CI}$ and FWHM leads to an almost constant behaviour up to $500^{\circ} \mathrm{C}$,

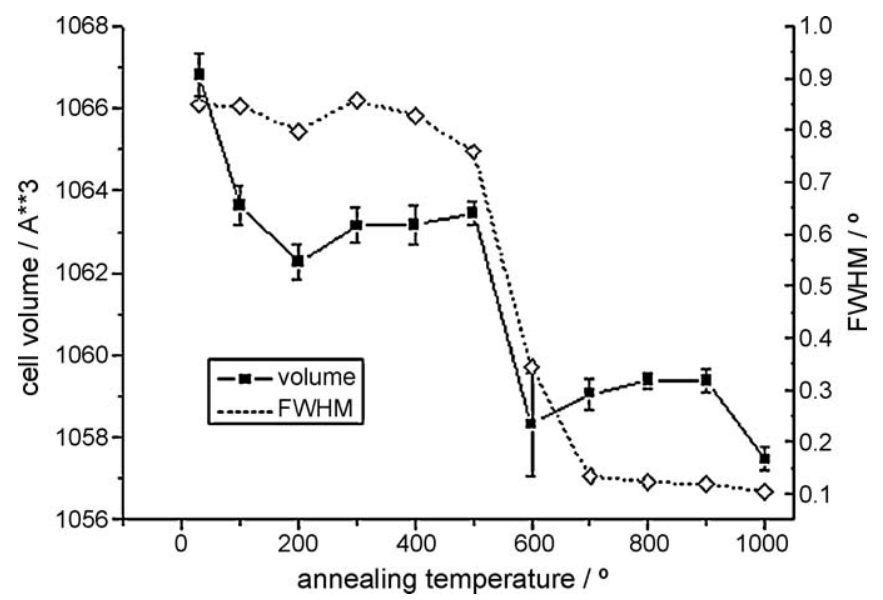

Fig. 1. Line halfwidth (FWHM, dotted line), and of the cell volume (solid line) as a function of cremation (annealing) temperature.

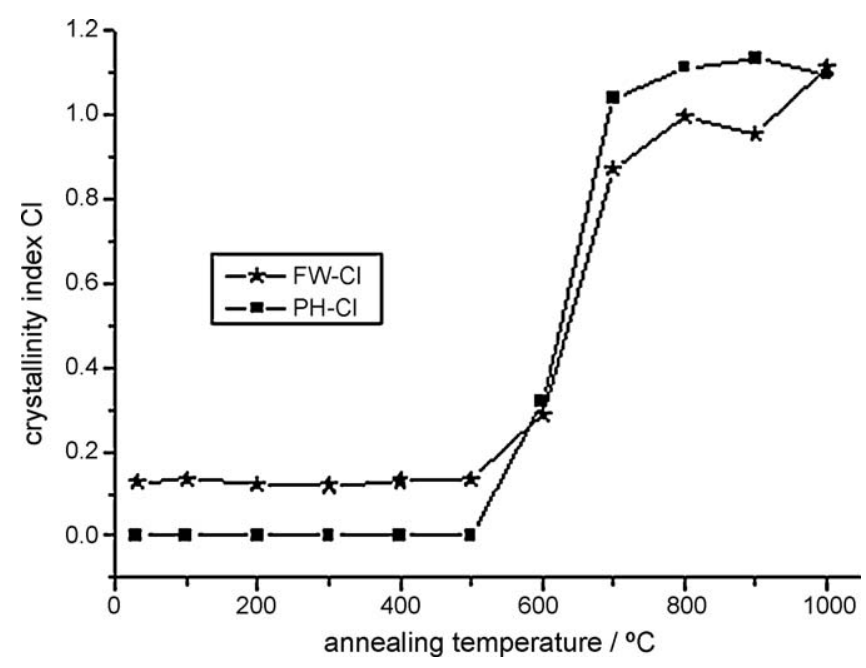

Fig. 2. Crystallinity indices as a function of annealing temperature. 
Table 1

Overview of the temperature induced changes in the analysed bones. Tibia exhibiting individual deviations in bone cross section colouration are indicated with the different colour in brackets.

\begin{tabular}{|c|c|c|c|c|c|c|c|c|c|c|c|c|c|}
\hline \multirow[t]{2}{*}{${ }^{\circ} \mathrm{C}$} & \multicolumn{3}{|c|}{ Indicators for degree of burning } & \multicolumn{5}{|c|}{$\begin{array}{l}\text { Indicators for the overall } \\
\text { modification process }\end{array}$} & \multirow{2}{*}{$\begin{array}{l}\text { DNA } \\
\text { Amplification } \\
\text { success }\end{array}$} & \multicolumn{4}{|c|}{ Stable isotopes: Rounded averages (\%) } \\
\hline & Colour & UV & Microstructure & $\begin{array}{l}\text { Mineral: } \\
\text { FWHM }\end{array}$ & $\begin{array}{l}\text { Mineral: HW-CI } \\
\text { and PB-CI }\end{array}$ & Mineral: cell-volume & Collagen & $\begin{array}{l}\text { Weight-loss (\%) and } \\
\text { temperature reaction }\end{array}$ & & $\begin{array}{l}\delta^{13} \mathrm{C} \\
\text { Collagen }\end{array}$ & $\begin{array}{l}\delta^{15} \mathrm{~N} \\
\text { Collagen }\end{array}$ & $\begin{array}{l}\delta^{13} \mathrm{C} \\
\text { Carbonate }\end{array}$ & $\begin{array}{l}\delta^{18} \mathrm{O} \\
\text { Carbonate }\end{array}$ \\
\hline 0 & Original & Original & Original & 0.87 & $\begin{array}{l}\text { Original (HW-CI: } \\
\text { about } 0.11 \text {, } \\
\text { PB-CI: } 0.00)\end{array}$ & ca. 1066.8 & $\begin{array}{l}11 \text { wt\%, } \\
\text { C/N-molar } 3.1\end{array}$ & - & $\begin{array}{l}\text { Reproducible } \\
\text { amplification } \\
\text { in all } \\
\text { investigated } \\
\text { samples }\end{array}$ & -14 & 6 & -7 & -9 \\
\hline 100 & & & & $\begin{array}{l}\text { Slightly } \\
\text { decreased } \\
\text { from ca. } \\
0.85 \text { to ca. } 0.78\end{array}$ & & $\begin{array}{l}\text { Decrease } \\
\text { (from ca. } 1067 \\
\text { down to } 1062 \text { ) }\end{array}$ & & $\begin{array}{l}\text { Region I: } 10 \% \text {, } \\
\text { endothermic reaction }\end{array}$ & & -14 & 6 & -6 & -9 \\
\hline 200 & Brown & Brown & First fissures & & & & $\begin{array}{l}1 \mathrm{wt} \% \text {, } \\
\mathrm{C} / \mathrm{N}-\mathrm{molar} 2.9\end{array}$ & & & -15 & 6 & -6 & -8 \\
\hline 300 & Black & Not visible & Black stain & & & $\begin{array}{l}\text { slightly increased } \\
\text { (up to ca. } 1064\end{array}$ & $\begin{array}{l}0.5 \mathrm{wt} \% \\
\mathrm{C} / \mathrm{N}-\mathrm{molar} 2\end{array}$ & & & -16 & 4 & -7 & -11 \\
\hline 400 & $\begin{array}{l}\text { Black }(\mathrm{TI}) \\
\text {-brown }\end{array}$ & Brown & $\begin{array}{l}\text { More fissures, } \\
\text { lamellae hardly } \\
\text { recognizable }\end{array}$ & & & & $\begin{array}{l}0.4 \mathrm{wt} \% \\
\mathrm{C} / \mathrm{N}-\mathrm{molar} 1.4\end{array}$ & $\begin{array}{l}\text { Region II: } \\
\text { additional } 20 \% \text {, } \\
\text { exothermic reaction }\end{array}$ & $\begin{array}{l}\text { Amplification } \\
\text { products not } \\
\text { in each case }\end{array}$ & -19 & 1 & -7 & -12 \\
\hline 500 & $\begin{array}{l}\text { Black (TI) } \\
\text {-grey }\end{array}$ & $\begin{array}{l}\text { Violet- } \\
\text { brown }\end{array}$ & $\begin{array}{l}\text { Overall structure } \\
\text { hardly visible, } \\
\text { fissures readily } \\
\text { apparent, reduced } \\
\text { birefringence }\end{array}$ & & & & $\begin{array}{l}0.2 \text { wt\%, } \\
\text { C/N-molar } 1.1\end{array}$ & & & -20 & 2 & -8 & -13 \\
\hline 600 & & & & $\begin{array}{l}\text { Significant } \\
\text { reduction (from } \\
\text { ca. } 0.75 \text { down } \\
\text { to } 0.13 \text { ) }\end{array}$ & $\begin{array}{l}\text { Sharp increase } \\
\text { (HW-CI: up } \\
\text { to 0.98, } \\
\text { PB-CI: } 1.1 \text { ) }\end{array}$ & $\begin{array}{l}\text { Sharp decline } \\
\text { (to ca. 1058) }\end{array}$ & $\begin{array}{l}0.3 \text { wt\%, } \\
\text { C/N-molar } 0.8\end{array}$ & & & -23 & 1 & -8 & -14 \\
\hline 700 & White & Violet & & & & $\begin{array}{l}\text { constant values } \\
\text { between } 1058 \\
\text { and } 1059\end{array}$ & $\begin{array}{l}0.3 \mathrm{wt} \% \\
\mathrm{C} / \mathrm{N}-\mathrm{molar} 1.9\end{array}$ & $\begin{array}{l}\text { Region III: about } \\
\text { additional 5\%, } \\
\text { exothermic reaction }\end{array}$ & & -22 & -1 & -11 & -17 \\
\hline 800 & $\begin{array}{l}\text { White-slightly } \\
\text { pink (TIII) }\end{array}$ & & $\begin{array}{l}\text { Structural elements } \\
\text { no longer } \\
\text { distinguishable, } \\
\text { no observable } \\
\text { birefringence }\end{array}$ & $\begin{array}{l}\text { Constantly } \\
\text { reduced value } \\
\text { (under 0.15) }\end{array}$ & $\begin{array}{l}\text { HW-CI: further } \\
\text { increase up to } 1 \text {, } \\
\text { PW-CI: constant } \\
\text { values }\end{array}$ & & $\begin{array}{l}0.2 \mathrm{wt} \% \\
\mathrm{C} / \mathrm{N}-\mathrm{molar} 1\end{array}$ & & No DNA & -21 & -2 & -10 & -17 \\
\hline 900 & $\begin{array}{l}\text { White-slightly } \\
\text { pink (TI) }\end{array}$ & & & & & & $\begin{array}{l}0.2 \text { wt\%, } \\
\text { C/N molar } 0.9\end{array}$ & & & -23 & -3 & 17 & -17 \\
\hline 1000 & White-pink & & & & & & $\begin{array}{l}\text { 0.1 wt\%, } \\
\text { C/N-molar } 0.8\end{array}$ & & & -23 & -1 & -8 & -16 \\
\hline
\end{tabular}


followed by a steep ascent up to $700{ }^{\circ} \mathrm{C}$ where it levels out at a value of $\sim 0.8$ to reach a value of 1.0 at $1000{ }^{\circ} \mathrm{C}$. The $\mathrm{PB}-\mathrm{CI}$ yields the same steep rise at $700{ }^{\circ} \mathrm{C}$, where the different absolute values below and above the transition are due to the different definitions of the CIs.

A further and more detailed size/strain analysis will be given elsewhere (Schneider et al., in prep.). The dependence of the unit cell volume on the cremation temperature is displayed in Fig. 1 also. Overall, a significant two step reduction of the cell volume is observed. First there is a significant reduction of the cell volume between the fresh bone and the $200{ }^{\circ} \mathrm{C}$ treatment temperatures. This stage is followed by a slight increase, possibly due to normal thermal expansion, leading to a plateau of the unit cell volume at $500{ }^{\circ} \mathrm{C}$. The second important change occurs between 500 and $600^{\circ} \mathrm{C}$, where the cell volume decreases substantially. No further change occurs up to the highest experimental cremation temperature.

Table 1 shows that the weight percentage average of the collagen retrieved from the unburned specimen and the sample cremated at $100{ }^{\circ} \mathrm{C}$ are both approximately $11 \%$. Loss of collagen due to the extraction method explains why the weight percentages never reach the expected $21 \%$, the typical figure for recent bone. Although determining the collagen content with this method is not very accurate, the results show that the main loss of collagen takes place between 100 and $200{ }^{\circ} \mathrm{C}$. Samples heated above $200{ }^{\circ} \mathrm{C}$ only show collagen contents under $1 \%$. An indicator for collagen quality is the $\mathrm{C} /$ $\mathrm{N}$-molar value [45]. In our findings, altered $\mathrm{C} / \mathrm{N}$-molar ratios below the suggested range from 2.9 to 3.6 (indicating intact collagen) are encountered in samples heated above $200{ }^{\circ} \mathrm{C}$ (Table 1 ).

The sample weight loss during cremation as measured by TGA is shown in Fig. 3, where three distinct regions of substantial weight loss followed by certain stabilization may be discerned: range I from room temperature to about $300{ }^{\circ} \mathrm{C}$ comprises a weight loss of some $10 \%$; range II from $300{ }^{\circ} \mathrm{C}$ to about $600^{\circ}$ shows the highest weight loss of another $20 \%$; and range III between 600 and $1000{ }^{\circ} \mathrm{C}$ displays a further but weaker weight loss of some $5 \%$. Thus the total weight loss up to a cremation temperature of $1000{ }^{\circ} \mathrm{C}$ amounts to some $35 \%$. The concurrent heat flow as measured by DSC also displays the discrimination of these three ranges. Endothermic behaviour is observed in range I, a smaller exothermic reaction is seen in range II, followed by another substantial exothermic reaction in range III.

\subsubsection{DNA analysis}

We succeeded in retrieving preserved DNA from samples taken from the experimentally cremated Tibia I that had been heated at

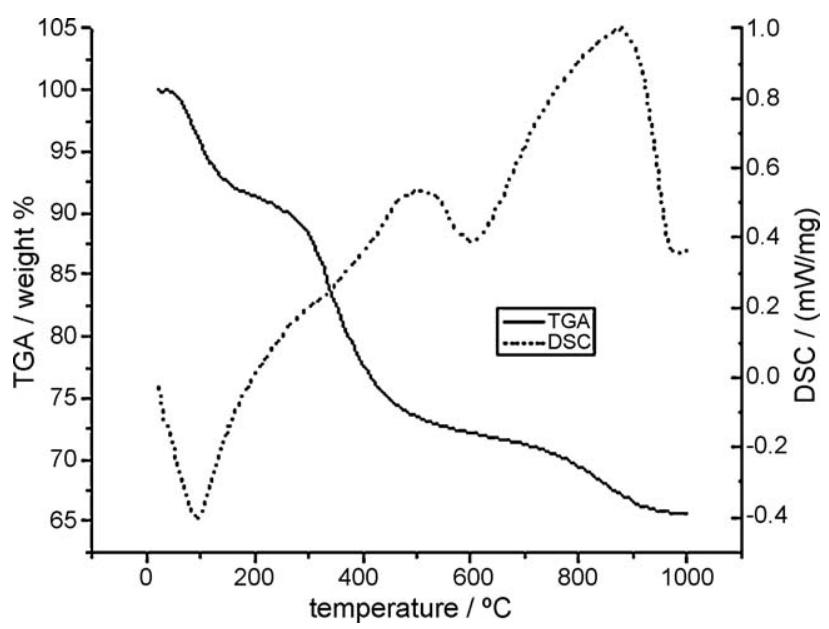

Fig. 3. Thermogravimetric (TGA) and differential thermal analyses (DSC) of uncremated cattle bone.

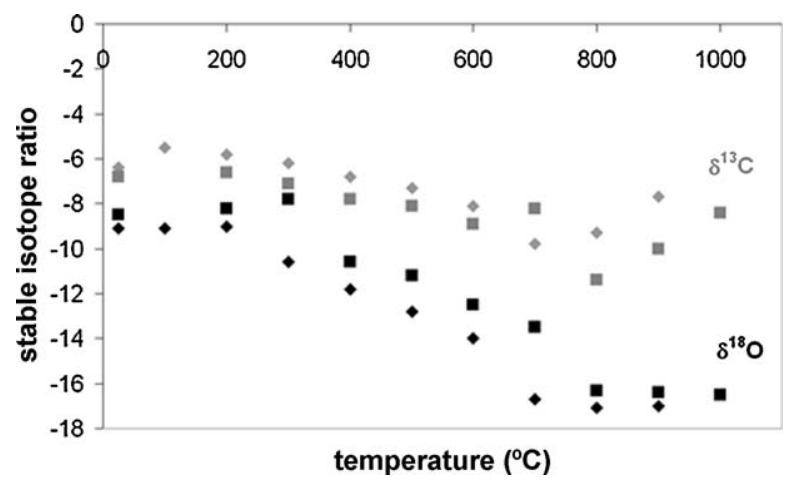

Fig. 4. Change of carbonate stable carbon and oxygen isotopic ratios with temperature. Diamonds: tibia I and squares: tibia II.

temperatures reaching $700{ }^{\circ} \mathrm{C}$. These were extracted according to a protocol provided by Yang et al. [39].

The same specimens yielded reproducible and amplifiable DNA when extracted according to the InViSorb-protocol, but only from the control (unburnt sample), the samples exposed to lower temperatures $\left(100,200\right.$, and $\left.300^{\circ} \mathrm{C}\right)$, and again the sample which had been cremated at $700{ }^{\circ} \mathrm{C}$.

Samples from Tibia III were heated longer. InViSorb extraction led to reproducible results up to a temperature of $600^{\circ} \mathrm{C}$. No PCR products were obtained from the samples exposed to temperatures between 700 and $1000{ }^{\circ} \mathrm{C}$.

For every gained amplification product sequencing led to the retrieval of the targeted sequence of the HVS1 region. All accompanying extraction and PCR controls remained negative.

\subsubsection{Stable isotope analyses}

Table 1 shows the mean $\delta$-values of collagen and carbonate from all Tibiae. Creation of an average was possible due to the similar change in the course of the isotope values of the samples from all investigated tibiae (cf. Fig. 4): The $\delta$-values of carbon and nitrogen from the organic extract become significantly depleted at temperatures above $200{ }^{\circ} \mathrm{C}$. Up to this temperature, the original isotopic signal is rather well retained. $\delta^{18} \mathrm{O}$ in the structural carbonate also becomes depleted. While this only holds true for $\delta^{13} \mathrm{C}$ in carbonate up to a temperature of $700^{\circ} \mathrm{C}$, the $\delta$-values become more positive again at higher temperatures (Fig. 4). The overall trend, however, points to significantly more negative $\delta$ values at higher temperatures (i.e. enrichment with the light isotope and depletion of the heavy one).

Strontium isotopes are heavier than $50 \mathrm{u}$ and theoretically no temperature-induced isotopic fractionation should take place. Indeed, no change in ${ }^{87} \mathrm{Sr} /{ }^{86} \mathrm{Sr}$ isotope ratios occurred in the course of heat exposure: All samples from Tibia I show ${ }^{87} \mathrm{Sr} /{ }^{86} \mathrm{Sr}-$ ratios of 0.70892 and samples from Tibia II had all values of 0.70895 .

\subsection{Samples from a modern crematory}

The recently burned remains from the crematory exhibited a colour ranging from black to grey to mainly white and emitted a bright violet fluorescence. The histological picture shows a black stain corresponding to those samples of the experimentally cremated bones burned at $300{ }^{\circ} \mathrm{C}$. Only parts of the sample $\mathrm{K} 97$ (Fig. 5) showed unchanged histological structures and birefringence (Fig. 5).

von Wurmb-Schwark et al. [34] were able to retrieve genetic fingerprints from ground bone fragments, which, however, did not match the genetic pattern of the corresponding buccal swabs. The $\delta^{13} \mathrm{C}$ and $\delta^{18} \mathrm{O}$ from the structural carbonate fraction of the recently 


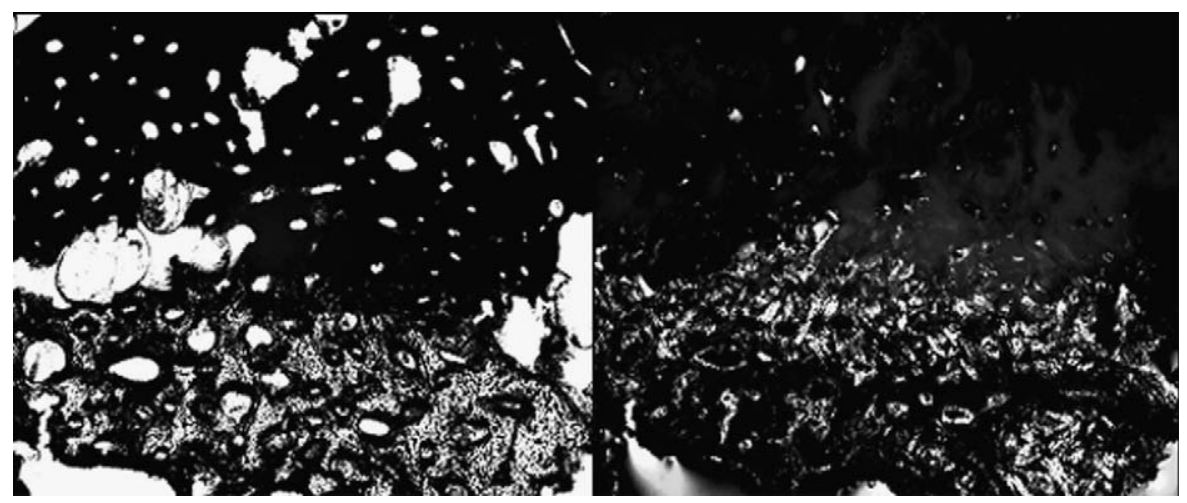

Fig. 5. Microstructural appearance under bright light (left) and polarized light (right) of the sample K 97 of the cremated remains from the recent crematory.

Table 2

Isotopic data in cremated remains from both a modern crematory facility and the control (cf. text).

\begin{tabular}{lll}
\hline Sample & $\delta^{18} \mathrm{O}(\%)$ carbonate & $\delta^{13} \mathrm{C}(\%)$ carbonate \\
\hline K91 & -17.4 & -23.43 \\
K92 & -16.58 & -22.81 \\
K93 & -13.81 & -24.87 \\
K94 & -16.91 & -25.37 \\
K95 & -15.23 & -24.96 \\
K96 & -16.42 & -22.87 \\
K97 & -15.51 & $-25,07$ \\
K98 & -17.13 & -21.29 \\
K99 & -12.65 & -24.18 \\
K100 & -13.69 & -25.4 \\
Mean & -15.53 & -24.03 \\
Control bone & -10.2 & -16.34 \\
\hline
\end{tabular}

cremated bones are shown in Table 2. They are all much more negative than the values of the control bone.

\section{Discussion}

\subsection{Overall high temperature modification process and indicators for burning degree}

The results in our study regarding the colour, microstructure, mineral and collagen of experimentally cremated samples exposed to different temperatures largely agree with other similar and previously published results [[5,8,10], and [46]]. However, due to the experimental design which, in contrast to earlier studies, involves all bone levels and combines these data with TGA und DSC, this study gives new insights about the relationships between different bone levels in the course of the high temperature modification process. To our knowledge UV-fluorescence of cremated bone was occasionally reported in the past (e.g. [47]) but never investigated on experimentally burned bones exposed to different temperatures. Details to the causes of fluorescence are still unknown, but it is assumed that both the collagen and mineral fraction of bone tissue contribute to the blue fluorescence of unburned bone [48].

By using TGA and DSC we can subdivide the high temperature modification processes taking place in bone tissue into three main ranges which are in accordance with the results regarding the different investigated bone levels.

It should be noted that because of different heating times (cf. material and methods) the results of the experimentally burned bones differ slightly at higher temperatures:

Within temperature range I (up to $300{ }^{\circ} \mathrm{C}$ ) as defined in the results, a small reduction of line width (FWHM in Fig. 1) up to $200{ }^{\circ} \mathrm{C}$ accompanied by a reduction in unit cell volume was observed. In conjunction with the concurrent TGA weight loss and a strong endothermic reaction (see Fig. 3), we conclude that this range is represented primarily by the loss of the absorbed and structural water. This is related to denaturation and loss of collagen, which is also shown by loss of the major part of collagen between 100 and $200{ }^{\circ} \mathrm{C}$ (wt.\%, Table 2 ) and the destroyed collagen composition (indicated by the $\mathrm{C} / \mathrm{N}$-molar-values below 2.9) by samples heated above $200^{\circ} \mathrm{C}$ (cf. also [21] and [50]).

In an intricate structural association of the apatite mineral with collagen down to the molecular level, apatite associates with "gaps" in the stacks of the collagen triple helix units. Thermal denaturing, loss of collagen, and the loss of structural water in protein may thus well cause a reduction in unit cell volume. Also, it may be responsible for the brownish colour (denaturated collagen) and fissures in the bone's microstructure (loss of elasticity due to low collagen yield, which may also hamper sectioning with a microtome) as observed in samples heated at $200{ }^{\circ} \mathrm{C}$. The brownish fluorescence is probably indicative of the increased role mineral fluorescence plays. The slight increase of cell volume up to $500{ }^{\circ} \mathrm{C}$ is due to normal thermal expansion.

Substantial weight loss was noted in temperature range II (up to $600{ }^{\circ} \mathrm{C}$ ) (Fig. 3, Table 1), which may be attributed to the combustion of occluded organic material and the loss of carbon via carbon dioxide. The beginning combustion of elementary carbon at $300{ }^{\circ} \mathrm{C}$ turned the whole bone sample and the histological cross section deeply black. It is also responsible for the lack of observable UVfluorescence, either by preventing the passage of UV-beams and so the stimulation of any fluorescence at all or by obscuring the fluorescence that is present.

Subsequent combustion of elementary carbon after its oxidation to $\mathrm{CO}_{2}$ in samples heated at $400{ }^{\circ} \mathrm{C}$ causes both colour and fluorescence to become visible again. Collagen is an organic, acidinsoluble substance and extractable from samples heated above $200{ }^{\circ} \mathrm{C}$, however, at this temperature it resembles charred organic material possessing an unknown composition (cf. C/N molar ratios) rather than collagen. Nonetheless, it shows that organic matter is still present even at temperatures above $400{ }^{\circ} \mathrm{C}$, contrary to the findings of Holden et al. [13], which have also been reported by Privat et al. [51] and Schurr et al. [31] in prehistoric cremated material. The reduced birefringence and the expanding fissure accumulation of samples heated at temperatures between 400 and $700{ }^{\circ} \mathrm{C}$ is also due to collagen loss. The grey surface of the samples and the brownish-violet UV-fluorescence that appears in samples heated in this temperature range can be explained by the subsequent disappearance of elementary carbon.

However, as soon as a major portion of organic material dissipates between 500 and $600{ }^{\circ} \mathrm{C}$ (see Fig. 3), more direct contact between the crystallite surfaces occurs. This opens up rapid surface diffusion pathways conductive for structural rearrangements of the remaining chemical constituents in the hydroxyapatite 
structure of the cremated bone (cf. endothermic peak of DSC at $500{ }^{\circ} \mathrm{C}$, Fig. 3). This in turn leads to the substantial drop of the hydroxyapatite unit cell volume observed between 500 and $600{ }^{\circ} \mathrm{C}$ (see Fig. 3) and causes an increase in crystallite size (or reduction in line width) as seen in Fig. 1. The recrystallization step at this temperature was also found in previous studies (for an overview see [5]).

In temperature range III (above $600^{\circ} \mathrm{C}$ ), further weight loss is associated with the solid state reaction. As the unit-cell volume decreases during the sintering process, we conclude that a chemical component residing in the bioapatite nanocrystals at lower temperature is driven-off during the high-temperature recrystallization process. We hypothesize that this structural component consists of $\mathrm{CO}_{3}{ }^{2-}$ ions: The rapid increase in crystallinity between 500 and $700{ }^{\circ} \mathrm{C}$, which is clearly reflected in the crystallinity index (Fig. 2) and the concurrent weight loss, depends on the gradual removal of carbonate ions at temperatures of $500{ }^{\circ} \mathrm{C}$ and greater (cf. $[52,49,53]$ ). This phenomenon is most probably closely connected with the evasion of $\mathrm{CO}_{2}$ at $600{ }^{\circ} \mathrm{C}$. Thus, $\mathrm{CO}_{2}$ bound to the adsorbed carbonate (superficial carbonate ions) is set free first, followed by $\mathrm{CO}_{2}$ bound within the mineral lattice of the structural carbonate. The latter does not happen at temperatures below $700{ }^{\circ} \mathrm{C}$. The thermogravimetric curve shows two heat releasing steps explained by this stepwise removal of carbonate ions. Both processes, however, constitute the prerequisite for the increase in crystal size (see also [54]).

The general assumption that bone mineral shows significant transformation to tricalcium phosphate could not be observed in this study. However, this work is consistent with other studies in which no such transformation was observable [55,15]. This difference has been ascribed to greater $\mathrm{Ca} / \mathrm{P}$ ratios and lower amounts of $\mathrm{HPO}_{4}{ }^{-}$and $\mathrm{Mg}$ [56]. It has been assumed that the formation of different mineral phases could be a function of individual age $[15,57]$.

Here it is important to stress the finding of the $\mathrm{MgO}$ (periclase) minority phase in samples annealed at $700{ }^{\circ} \mathrm{C}$ and above, something that will be discussed in more detail in Schneider et al. (in prep).

The grey to white colour of the samples and most likely the bright violet UV-fluorescence of samples heated above $600{ }^{\circ} \mathrm{C}$ are the result of altered mineral organisation. Histological appearance becomes completely homogenous (as a sign of altered mineral organisation) at temperatures slightly above $800{ }^{\circ} \mathrm{C}$, indicating that the bone interior is affected by the solid state reaction later than the exterior surface, which is directly exposed to the heat. The curious pink colour observed in our experiment in samples exposed to temperatures above $800{ }^{\circ} \mathrm{C}$ was also found in earlier studies (e.g. [10]) and it had been reported that copper can produce such a pink colour in cremated bone (Dunlop in [5]).

The knowledge of the overall high temperature modification process involving all bone levels should enable us to assess the burning degree of cremated bones using simplified methods.

However, the recent remains from a modern crematory exhibit a black to grey/white colour on the outer surface and violet fluorescence. This leads to the assumption that the bones have been exposed to a degree of burning equal to bones experimentally cremated in the late stage of temperature range II or temperature range III (cf. Table 1 ).

Surprisingly, the histological appearance of the cremated bone fragments from the modern crematory corresponds to that of experimentally cremated samples within the late temperature range I. While the outer surface is most probably exposed to very high temperatures in the crematory oven, the inside of the bones is not fully incinerated, indicating that the duration of heat exposure was too short in order to significantly alter the bone's interior (see $[6,13,58]$, also compare experimentally burned bones).
This is a very important finding for the assessment of the applicability of DNA- and stable isotope analyses for identification purposes (see above). The interior of bones displaying significant alteration on the exterior surface may indeed not reach high temperatures at all. Therefore, biomolecules may still be present there. The implication for forensic science is that although the maximum temperature can be assessed based on the bone's exterior, only a histological investigation provides information regarding the ultimate degree of burning and thus the feasibility of performing DNA- and stable isotope analyses.

\subsection{Chance of DNA retrieval from cremated bones}

Short fragments of mtDNA were amplifiable in samples of both tibiae tested that had been exposed to temperatures up to $600{ }^{\circ} \mathrm{C}$ (temperature ranges I and II). Even the sample from Tibia I, which had been heated to $700{ }^{\circ} \mathrm{C}$, successfully yielded reproducibly amplifiable DNA, albeit of unexceptional quality. In this case, the shorter time of heat exposure may be responsible, and not only temperature but also cremation time are crucial for the final detection limit.

Earlier studies have proved that DNA can be recovered from the exterior of completely burned remains (for a review see [5]). Most of these focus on the retrieval of amplifiable DNA from archaeological cremated remains $[17,19,20]$. Tsuchimochi et al. [59] also found in an experimental approach that chromosomal DNA typing was possible on teeth heated up to $300{ }^{\circ} \mathrm{C}$. In contrast to this study we analysed short fragments of mtDNA. The likelihood of its preservation is known to be greater in degraded samples due to the higher initial amount in cells compared to chromosomal DNA. This explains why we could retrieve DNA in bones heated at higher temperatures.

Our detection limit for DNA fragments coincides with the onset of the solid state reaction of bioapatite. We believe that this indicates a causal relationship since the possibility of binding DNA molecules by their negatively charged phosphate backbone to the hydroxyapatite [60] enhances the probability for stability and preservation of the molecule in archaeological bone [61,62]. Expectedly, no DNA will then be amplifiable from fully cremated bone (temperature range III). However, insufficiently cremated bones (temperature ranges I and II) may be suitable for DNA analysis.

These data from experimentally burned bones suggest that it should be possible to retrieve DNA from bones originating from a modern crematory because of incomplete cremation, as shown above. However, von Wurmb-Schwark et al. [34] only found nonauthentic DNA patterns in the cremated remains and showed that the most likely source of contamination was the treatment of the cremated bones in the crematory (e.g. removing of anorganic remains with unprotected hands, grinding of the bones in a mill).

In conclusion, DNA analyses (mainly mtDNA typing) of presumably fully cremated bones was possible due to incompletely burned portions of the bone interior caused by variable cremation conditions. In cases where the identification of cremated human remains (e.g. after mass disasters involving fire) is necessary it is advisable to perform histological screening of the burned bones to assess the degree of burning in the bone's interior. If the histological images show black stains, birefringence under polarised light, or remnants of distinguishable structural elements (like osteons), then DNA analyses should be attempted.

The results gathered by von Wurmb-Schwark et al. [34] highlight the importance of knowing how samples were handled in order to assess the contamination risk. In light of this, collection of samples should take place as soon as possible.

In most cases this might not be achievable if DNA analyses on cremated remains from a recent crematory (e.g. for paternity 
testing) are to be performed. In this case, DNA analysis is not advisable because of the great potential for contamination that exists as bones pass from the crematory to the genetic laboratory.

\subsection{Success of stable isotope analyses on cremated bones}

All $\delta$-values decrease considerably with increasing temperature in the experimentally cremated bones. Stable isotope values of carbonate in recently cremated bones from a modern crematory are also heavily depleted. This result was unexpected, since it was presumed that the more volatile ${ }^{12} \mathrm{C}^{16} \mathrm{O}_{2}$ would preferably be combusted compared to the heavier ${ }^{13} \mathrm{C}^{18} \mathrm{O}_{2}$ molecule and that, consequently, the remaining sample would be enriched with the heavy isotopes. In general, the heavier isotope forms stronger intramolecular bonds. Light elements like carbon, nitrogen and oxygen preferably form covalent bonds which are rather elastic and less rigid than ionic bonds permitting for a certain degree of vibration. The higher the mass of an isotope, the smaller the frequency of vibration tends to be. Consequently, it is generally easier to break covalent bonds where light isotopes are involved, which is exactly what happens in nature. Our results therefore require an explanation that is related to heat exposure.

Radiocarbon dating of cremated bones revealed that $\delta^{13} \mathrm{C}$ values are as depleted as those found in our experiment and even lower (as low as $-30 \%$; [29]). This $\delta^{13} \mathrm{C}$ shift was tentatively explained by the combustion of portions of the structural carbonate [28], or by the combustion of $\mathrm{CO}_{2}$ [22]. Munro et al. $[63,64]$ measured $\delta^{18} \mathrm{O}$ in the bioapatite phosphate and carbonate after experimental heat exposure of temperatures up to $900{ }^{\circ} \mathrm{C}$, and in both materials also found a temperature-related shift to significantly depleted values. They explained the shift at lower temperatures (between 300 and $400^{\circ} \mathrm{C}$ ) as being the result of an oxygen isotope exchange between bioapatite and atmospheric water vapour because their samples had been exposed to air. Since the heated specimens in our experiment were not sealed from the atmosphere, we must take this mechanism into account as well, i.e., as an exchange reaction with an external low ${ }^{18} \mathrm{O}$ reservoir. However, Munro et al. [63,64] suggest a second effect at temperatures of $700{ }^{\circ} \mathrm{C}$ and greater, probably due to structural and phase related changes including the loss of structural carbonate and the formation of $\mathrm{CaO}$.

Munro et al. [64] also measured the isotopic composition of structural carbonate carbon during heating of up to $900{ }^{\circ} \mathrm{C}$. Contrary to our results, they report that the carbon isotope composition remains constant during heating up to $650^{\circ} \mathrm{C}$. At higher temperatures they observed a rapid enrichment, which they explain as the tendency of ${ }^{13} \mathrm{C}$ to be more tightly bound to the bioapatite and therefore is likely to be retained at higher temperatures. The difference seen in our results might be explained by differing sample preparation. Munro et al. [64] did not remove secondary carbonates or organic structure by use of a weak acid and sodium hypochlorite.

Other published data on changes of $\delta^{13} \mathrm{C}$ and $\delta^{15} \mathrm{~N}$ in bone collagen following experimental heat exposure differ from our results, for example, both Deniro et al. [21] and Schurr et al. [31] found enrichment of ${ }^{15} \mathrm{~N}$ at higher temperatures. Deniro et al. [21] also reported more negative $\delta^{13} \mathrm{C}$-values, something not confirmed by the recent study of Schurr et al. [31] where $\delta^{13} \mathrm{C}$ remained unchanged. In both studies, temperature during experimental heat exposure did not exceed $600{ }^{\circ} \mathrm{C}$. In our experiment, both $\delta^{13} \mathrm{C}$ and $\delta^{15} \mathrm{~N}$ became progressively depleted in the heavy isotope. Interestingly, by investigating archaeological cremated bones, Schurr et al. [31] found the specimens depleted in ${ }^{13} \mathrm{C}$ yet still enriched with ${ }^{15} \mathrm{~N}$. The authors tentatively suggest that the presence of humic substances (which play no role in our experiment) as the cause. It may be that the experimental conditions created this discrepancy, since it is hard to imagine that $\delta^{13} \mathrm{C}$ remains unchanged while $\delta^{15} \mathrm{~N}$ values are altered. Furthermore, it would be expected that $\delta^{13} \mathrm{C}$ values are significantly more negative in archaeological cremations (see radiocarbon dating).

As mentioned previously, all $\delta$-values in our experiment became significantly more negative (less positive) at higher temperatures. These results can be explained as follows. Isotopic fractionation effects which occur under natural, physiological conditions (thermodynamic or enzyme related) cease to occur at higher temperatures, since heat provides the entire system with so much energy that breakage of intramolecular bonds, regardless of whether a light or a heavy isotope is involved, proceeds easily. A plot of $\ln \alpha$ (fractionation factor) versus $1 / T$ (temperature) will have a slope of zero at high temperatures [65]. As long as the heat exposure takes place at oxidizing conditions as conducted in our experiment, cremation leads to the formation of oxidized bone components (cf. black colouring and mineral features above). Thus, the organic and also the combusted inorganic material are eliminated by oxidation, leaving reduced components behind. The light isotopes preferably enter into reduced components, while the heavy isotopes prefer strong bonds which are prevalent in oxidized compounds. In the course of cremating bones, phases are generated which are not in a state of equilibrium, leading to a unidirectional isotope exchange. This possibly offers an explanation for the overall and reproducible depletion of heavy isotopes from the cremated samples in our experiment. As a hypothetical side effect, the combustion of oxidized material with strong intramolecular bond energies may facilitate the delivery of the surplus energy which had been supplied to the bone by the heat exposure.

Stable isotope analysis of light elements $(\mathrm{C}, \mathrm{N})$ can provide clues to the life history of an individual, while ${ }^{18} \mathrm{O}$-isotope analysis of bone apatite reveals information on an individual's probable geographic origin [26]. If DNA analysis fails, information gathered in this way could prove very useful, possibly leading to the identification of an individual based upon cremated bone remains. Unfortunately, our results show that stable isotope analysis is only reliable on bones heated at temperatures up to $200{ }^{\circ} \mathrm{C}$. To assess the chance of a successful application of this method only a superficial inspection of the bone is necessary, since stable isotope values are a mixture of all bone parts used. The completely burned exterior surface of bone is sufficient to alter the values even if the interior structure is less burned.

For forensic science purposes, this implies that if any portion of a bone sample exhibits a black, grey or white (fully cremated) colour, the stable isotope values of light elements may be altered and this analytic method should not be applied. Only bone possessing an original or brownish colour or displaying original blue fluorescence should be sampled for stable isotope analyses of light elements.

The ${ }^{87} \mathrm{Sr} /{ }^{86} \mathrm{Sr}$ ratio in bone bioapatite does not change even after a heat exposure of $1000{ }^{\circ} \mathrm{C}$. It should be noted that the preparation of the bioapatite involves a heating step at $500{ }^{\circ} \mathrm{C}$, which means that all specimens that had initially been exposed to lower temperatures were actually re-heated, yet the stable strontium isotopic ratio was still not altered. In a previous experiment, it was shown that strontium remains stable after experimental heat exposure up to $1000{ }^{\circ} \mathrm{C}$ [66]. According to the atomic weight of $\mathrm{Sr}$ and the relatively small weight differences existing between the stable isotopes, no measurable fractionation processes occur.

We therefore conclude that this is the only tested method that can be safely applied to fully cremated bone. Depending on the scenario (e.g. mass disaster, recovery of completely burned bones of a murder victim, etc.) this fact certainly plays a major role in the analysis of human remains when only fully cremated bones are available. It can aid in efforts to determine the geographical origin 
of a person, which is often the first step in the individual identification process.

\section{Conclusion}

In sum, our experiments led to the following conclusions regarding DNA and stable isotope analyses of cremated bone in the forensic and anthropological context:

Authentic, amplifiable DNA could be retrieved from experimentally cremated bones even at temperatures of 600 and $700{ }^{\circ} \mathrm{C}$, whereby the duration of heat exposure appears to play an important role.

The potential of cremated bones containing retrievable DNA can only be assessed by histological investigation, which is necessary because biomolecules may still be present in the bone's interior structure. Even when the bone's outer surface is severely charred by obvious exposure to high temperatures, the molecular integrity of elements in the interior structure tends to be better preserved.

Analyses of bone remains from a modern crematory have shown that even though DNA can be amplified, its definite origin is often questionable. Because of the high risk of contamination, DNAanalysis of cremated remains from the modern crematory situation is not advised. This result has also to be taken into account for genetic analysis of archaeological cremated remains, where contamination may even play a greater role due to the unknown handling of samples after excavation.

Stable isotopic values of the light elements carbon, nitrogen and oxygen remain unchanged up to a maximum temperature of $200^{\circ} \mathrm{C}$; biological signals should not be expected from bones exposed to temperatures higher than this. Bones producing reliable stable isotope values of light elements can be recognized by original or brown colouration of the exterior surface.

Stable isotopic values of the heavy element strontium remain unaltered up to a temperature of $1000{ }^{\circ} \mathrm{C}$. This analytic method will therefore lead to accurate data that can provide hints to the geographic origin of an individual, even when conducted on fully cremated bones.

\section{Conflict of interest statement}

We disclose any financial and personal relationships with other people or organisations that could inappropriately influence our work.

\section{Acknowledgments}

We thank Prof. Dr. Joris Peters and Britta Möllenkamp, Veterinary Department of the Ludwig-Maximallians-University of Munich, for providing the cattle bones, as well as to Dr. Kai-Uwe Hess, Department of Earth and Environmental Science of LudwigMaximillians-University of Munich, who carried out the thermogravimetric and differential thermal analyses. We are also deeply grateful to Dr. George McGlynn and Nadja Hoke for editing the English text.

\section{References}

[1] P. Mareaux, La cremation dans le monde, Reson@nce, ĹActualité des Professionnels Funéraires 38 (2008) 15.

[2] Cremation Association of North America, Final 2005 Statistics and Projections to the Year 2025, 2006 Preliminary Data, SmithBucklin Corp., Chicago, 2007.

[3] L. Fanton, K. Jdeed, S. Tilhet-Coartet, D. Malicier, Criminal burning, Forensic Sci. Int. 158 (2006) 87-93.

[4] C.L. Nelson, D.C. Winston, Detection of medical examiner cases from review of cremation requests, Am. J. Forensic Med. Pathol. 27 (2006) 103-105.
[5] D.H. Ubelaker, The forensic evaluation of burned skeletal remains: a synthesis, Forensic Sci. Int 183 (2009) 1-5.

[6] P. Shipman, G. Foster, M.J. Schoeninger, Burnt bones and teeth: an experimental study of color, morphology, crystal structure and shrinkage, J. Archaeol. Sci. 11 (1984) 307-325.

[7] J.E. Buikstra, M. Swegle, Bone modification due to burning: experimental evidence, in: R. Bonnichsen, M.H. Sorg (Eds.), Bone Modification, Center for the Study of the First Americans, Institute for Quaternary Studies, Peopling of the Americas Publications, University of Maine, Orono, 1989, pp. 247-258.

[8] P.J. Walker, K.P. Miller, R. Richman, Time temperature, and oxygen availability: An experimental study of the effects of environmental conditions on the color and organic content of cremated bone, in: C.W. Schmidt, S.A. Symes (Eds.), The Analysis of Burned Human Remains, Academic Press, London, 2008, pp. 129-136.

[9] G. Quatrehomme, M. Bolla, M. Muller, J.P. Rocca, G. Grevin, P. Bailet, A. Ollier, Technical note-experimental single controlled study of burned bones: contribution of scanning electron microscopy, J. Forensic Sci. 43 (1998) 417-422.

[10] M. Hanson, C.R. Cain, Examining histology to identify burned bone, J. Archaeol. Sci. 34 (2007) 1902-1913.

[11] E. Swillens, P. Pollandt, J. Wahl, Zur Quantifizierung von Knochenverbrennungstemperaturen durch Röntgenbeugungs-Intensitätsmessungen, Beitr. z. Archäozool. u. Prähist. Anthrop. IV (2003) 204-210

[12] A. Sillen, T. Hoering, Chemical characterization of burnt bones from Swartkrans, in: C.K. Brain (Ed.), Swartkrans: A Cave's chronicle of Early Man, Transvaal Museum Monograph 8, Transvaal Museum, Pretoria, 1993, pp. 243-249.

[13] J.L. Holden, P.P. Phakey, J.G. Clement, Scanning electron microscope observations of heat-treated human bone, Forensic Sci. Int. 74 (1995) 29-45.

[14] I. Reiche, C. Vignaud, M. Menu, The crystallinity of ancient bone and dentine: new insights by transmission electron microsopy, Archaeometry 44 (2002) 447-459.

[15] J.C. Hiller, T.J.U. Thompson, M.P. Evison, A.T. Chamberlain, T.J. Wess, Bone mineral change during experimental heating: an X-ray scattering investigation, Biomaterials 24 (2003) 5091-5097.

[16] M.C. Stiner, S.L. Kuhn, S. Weiner, O. Bar-Yosef, Differential burning, recrystallization and fragmentation of archaeological bone, J. Archaeol. Sci. 22 (1995) 223237.

[17] K.A. Brown, K. O'Donoghue, T.A. Brown, DNA in cremated bones from an early bronze age cemetery cairn, Int. J. Osteoarch. 5 (1995) 181-187.

[18] C. Cattaneo, S. DiMartino, S. Scali, O.E. Craig, M. Grandi, R.J. Sokol, Determining the human origin of fragments of burnt bone: a comparative study of histological, immunological and DNA techniques, Forensic Sci. Int. 102 (1999) 181-191.

[19] P. Chattopadhyay, Analysis of burnt bones by DNA fluorescent technology: a case study, Genome Lett. 2 (2003) 162-164.

[20] C.M. Pusch, M. Broghammer, M. Scholz, Cremation practices and the survival of ancient DNA: burnt bone analyses via RAPD-mediated PCR, Anthropol. Anz. 58 (2000) 237-251.

[21] M.J. Deniro, M.J. Schoeninger, C.A. Hastorf, Effect of heating on the stable carbon and nitrogen isotope ratios of bone collagen, J. Archaeol. Sci. 12 (1985) 1-7.

[22] C.A. Juarez, Strontium and geolocation, the pathway to identification for deceases undocumented Mexican border-crossers: a preliminary report, J. Forensic Sci. 53 (2008) 46-49.

[23] M.A. Katzenberg, H.R. Krouse, Application of stable isotope variation in human tissues to problems in identification, Can. Soc. Forensic Sci. J. 22 (1989) 7-20.

[24] W. Meier-Augenstein, R.H. Liu, Forensic applications of isotope ratio mass spectrometry, in: J. Yinon (Ed.), Advances in Forensic Applications of Mass Spectrometry, CRC Press, Boca Raton, 2003, pp. 149-180.

[25] E. Rauch, S. Rummel, C. Lehn, A. Büttner, Origin assignment of unidentified corpses by use of stable isotope ratios of light (bio-) and heavy (geo-) elements-a case report, Forensic Sci. Int. 168 (2007) 215-218.

[26] W. Meier-Augenstein, I. Fraser, Forensic isotope analysis leads to the identification of a multilated murder victim, Sci. Justice 48 (2008) 153-159.

[27] M.A. Katzenberg, Stable isotopes analysis: a tool for studying past diet, demography, and life history, in: M.A. Katzenberg, S.R. Saunders (Eds.), Biological Anthropology of the Human Skeleton, John Wiley \& Sons, New York, 2000, pp. 305-326.

[28] J.N. Lanting, A.T. Aerts-Bijma, J. van der Plicht, Dating of cremated bones, Radiocarbon 43 (2001) 249-254.

[29] P. Naysmith, E.M. Scott, G.T. Cook, J. Heinemeier, J. van der Plicht, M. van Strydonck, C. Bronk Ramsey, P.M. Grootes, S.P.H.T. Freeman, A cremated bone intercomparison study, Radiocarbon 49 (2007) 403-408.

[30] J. Olsen, J. Heinemeier, P. Bennike, C. Krause, K.M. Hornstrup, H. Thrane, Characterisation and blind testing of radiocarbon dating of cremated bone, J. Archaeol. Sci. 35 (2008) 791-800.

[31] M.R. Schurr, R.G. Hayes, D.C. Cook, Thermally induced changes in the stable carbon and nitrogen isotope ratios of charred bones, in: C.W. Schmidt, S.A. Symes (Eds.), The Analysis of Burned Human Remains, Academic Press, London, 2008, pp. 95-108.

[32] H.W. Krueger, Exchange of carbon with biological apatite, J. Archaeol. Sci. 18 (1991) 355-361.

[33] J.I. McKinley, Bronze age 'barrows' and funerary rites and rituals of cremation, Proc. Prehist. Soc. 63 (1997) 129-145.

[34] N. von Wurmb-Schwark, A. Ringleb, M. Gebühr, E. Simeoni, Genetic analysis of modern and historical burned human remains, Anthrop. Anz. 63 (2005) 1-12.

[35] A. Person, H. Bocherens, J.-F. Saliège, F. Paris, V. Zeitoun, M. Gerard, Early diagenetic evolution of bone phosphate: an X-ray diffractometry analysis, J. Archaeol. Sci. 22 (1995) 211-221.

[36] H.M. Rietveld, A profile refinement method for nuclear and magnetic structures, J. Appl. Cryst. 2 (1969) 65-71. 
[37] Y. Suetsugu, J. Tanaka, Crystal growth and structure analysis of twin-free monoclinic hydroxyapatite, J. Mater. Sci. Mater. Med. 13 (2002) 767-772.

[38] J. Rodriguez-Carvajal, Programme Fullprof.2k, Version 4.00-May 2007-ILLJCR, Institute Laue Langevin, Grenoble, France, 2007.

[39] D.Y. Yang, B. Eng, J.S. Waye, J.C. Dudar, S.R. Saunders, Technical note: improved DNA extraction from ancient bones using silica based spin columns, Am. J. Phys. Anthropol. 105 (1998) 539-543.

[40] R. Bollongino, C.J. Edwards, K.W. Alt, J. Burger, D.G. Bradley, Early history of European domestic cattle as revealed by ancient DNA, Biol. Lett. 2 (2006) 155159.

[41] R. Longin, New method of collagen extraction for radiocarbon dating, Nature 230 (1971) 241-242.

[42] G. Grupe, D. Heinrich, J. Peters, A brackish water aquatic foodweb: trophic levels and salinity gradients in the Schlei fjord, Nothern Germany, in Viking and medieval times, J. Archaeol. Sci. 36 (2009) 2125-2144.

[43] M. Balasse, H. Bocherens, A. Mariotti, Intra-bone variability of collagen and apatite isotopic composition used as evidence of a change of diet, J. Archaeol. Sci. 26 (1999) 593-598.

[44] T.E. Berger, J. Peters, G. Grupe, Life history of a mule (c. 160 AD) from the Roman fort Biriciana/Weißenburg (Upper Bavaria) as revealed by serial stable isotope analysis of dental tissue, Int. J. Osteoarchaeol., in press, www.interscience. wiley.com, doi:10/1002/oa1013.

[45] M.J. Deniro, Postmortem preservation and alteration of in vivo bone collagen isotope ratio in relation to palaeodietary reconstruction, Nature 317 (1985) 806809.

[46] J. McKinley, The analysis of cremated bone, in: M. Cox, S. Mays (Eds.), Human Osteology in Archaeology and Forensic Science, Cambridge University Press, London, 2000, pp. 403-421.

[47] M.W. Warren, A.B. Falsetti, W.F. Hamilton, L.J. Levine, Evidence of arteriosclerosis in cremated remains, Am. J. Forensic Med. Pathol. 20 (1999) 277-280.

[48] C.H. Bachman, E.H. Ellis, Fluorescence of bone, Nature 206 (1965) 1328-1331.

[49] G. Piga, A. Malgosa, T.J.U. Thompson, S. Enzo, A new calibration of the XRD technique for the study of archaeological burned human remains, J. Archaeol. Sci. 35 (2008) 2171-2178.

[50] S.E. Etok, E. Valsami-Jones, T.J. Wess, J.C. Hiller, C.A. Maxwell, K.D. Rogers, D.A. Maning, M.L. White, E. Lopez-Capel, M.J. Collins, M. Buckley, K.E. Penkman, S.L. Woodgate, Structural and chemical changes of thermally treated bone apatite, J. Mater. Sci. 42 (2007) 9807-9816.

[51] K.L. Privat, T.C. O'Connel, M.P. Richards, Stable isotope analysis of human and faunal remains from the anglo-saxon cemetery at Berinsfield, Oxfordshire: dietary and social implications, J. Archaeol. Sci. 29 (2002) 779-790.
[52] R. Legros, N. Balmain, G. Bonel, On the structure and composition of the mineral phase of periosteal bone, J. Chem. Res. 5 (1986) 8-9.

[53] C. Oriozola, M. Martnez-Blanes, Estimate of firing temperatures through bonebased chalcolithic decorated pottery, J. Therm. Anal. Calorim. 87 (2007) 135-141

[54] S.N. Danilchenko, V.A. Pokrovski, V.M. Bogatyrov, L.F. Sukhodub, B. Sulkio-Cleff, Carbonate location in bone tissue mineral by X-ray diffraction and temperatureprogrammed desorption mass spectrometry, Cryst. Res. Technol. 40 (2005) 692697.

[55] K.D. Rochers, P. Daniels, An X-ray diffraction study of the effects of heat treatment on bone mineral microstructure, Biomaterials 23 (2002) 2577-2585.

[56] A. Bigi, E. Foresti, R. Gregorini, A. Ripamonti, N. Roveri, J.S. Shah, The role of magnesium on the structure of biological apatites, Calcif. Tissue Int. 50 (1992) 439-444.

[57] J.L. Holden, J.G. Clement, P.P. Phakey, Age and temperature related changes to the ultrastructure and composition of human bone mineral, J. Bone Miner. Res. 10 (1995) 1400-1409.

[58] J.L. Holden, P.P. Phakey, J.G. Clement, Scanning electron microscope observations of incinerated human femoral bone: a case study, Forensic Sci. Int. 74 (1995) 17-28.

[59] T. Tsuchimochi, M. Iwasa, Y. Maeno, H. Koyama, H. Inoue, I. Isobe, R. Matoba, M. Yokoi, M. Nagao, Chelating resin-based extraction of DNA from dental pulp and sex determination from incinerated teeth with Y-chromosomal alphoid repeat and short tandem repeats, Am. J. Forensic Med. Pathol. 23 (2002) 268-271.

[60] A.V. Ogram, M.L. Mathod, J.B. Harsh, J. Boyle, C.A. Pettigrew, Effects of DNA polymer length on its adsorption to soils, Appl. Environ. Microbiol. 60 (1994) 393-396.

[61] E.M. Geigl, U. Baumer, J. Koller, New approaches to study the preservation of biopolymers in fossil bones, Environ. Chem. Lett. 2 (2004) 45-48.

[62] A. Götherström, M.J. Collins, A. Angerbjörn, K. Lidén, Bone preservation and DNA amplification, Archaeometry 44 (2002) 395-404.

[63] L.E. Munro, F.J. Longstaffe, C.D. White, Burning and boiling of modern deer bone: effects on the oxygen isotope composition of bioapatite phosphate, Palaeogeogr. Palaeoclimat. Palaeoecol. 249 (2007) 90-102.

[64] L.E. Munro, F.J. Longstaffe, C.D. White, Effects of heating on the carbon and oxygen-isotope compositions of structural carbonate in bioapatite from modern deer bone, Palaeogeogr. Palaeoclimat. Palaeoecol. 266 (2008) 142-150.

[65] J. Bigeleisen, Temperature dependence of the isotope chemistry of the heavy elements, Proc. Natl. Acad. Sci. U.S.A. 93 (1996) 9393-9396.

[66] G. Grupe, S. Hummel, Trace element studies on experimentally cremated bone, I. Alteration of the chemical composition at high temperatures, J. Archaeol. Sci. 18 (1991) 177-186. 